11. Culbertson M, Smolen M. Attitudes toward personalities and lifestyles of obese adults. Journal of Nursing Education 1999; 38(2): 84

12. Garner C, Nicol G. Comparison of male and female nurses' attitudes toward obesity. Percept Mot Skills 1998; 86(3): 1442.

13. Hoppe R, Ogden J. Practice nurses' beliefs about obesity and weight related interventions in primary care. Int J Obes Relat Metab Disord 1997; 21(2): 141-6.

14. Maiman L, Wang V, Beckler M, Finlay J, Simonson M. Attitudes toward obesity and the obese among professionals. J Am Diet Assoc 1979; 74: 331-336.

15. Campbell K, Engel H, Timperio A, Cooper C, Crawford D. Obesity management: Australian general practitioners' attitudes and practices. Obes Res 2000; 8(6): 459-66.

16. Campbell K, Crawford D. Management of obesity: Attitudes and practices of Australian dietitians. Int J Obes Relat Metab Disord 2000; 24 (6): 701-10.

17. Jeffcoate W. Obesity is a disease: Food for thought. Lancet 1998; 351(9106): 903-904.

18. Rothblum E. Women and weight: Fad and fiction. J Psychol 1990; 124(1): 5-24.
19. Bouchard C, Tremblay A, Despres J, Nadeau A, Lupietn P, Theriault G, Dussalt J, Moorjani S, Pinault S, Fournier G. The response to long term overfeeding in identical twins. $N$ Eng J Med 1990; 322: 1477-1482.

20. Garner D, Wooley S. Confronting the failure of behavioral and dietary treatments for obesity. Clin Psychol Rev 1991; 11: 729-780.

21. Kirkland L, Anderson R. Achieving healthy weights. Can Fam Phys 1993; 39:157-8, 161-2.

22. Miller W. How effective are traditional dietary and exercise interventions for weight loss? Medicine \& Science in Sports \& Exercise 1999; 31(8): 1129-34.

23. Berg F. The health risks of weight loss. The Health Risks of Obesity. Healthy Living Institute. Hettinger, ND: Decker Periodicals, 1993.

24. Ernsberger P, Haskew P. Rethinking obesity: An alternative view of its health implications. J Obes Weight Regulation 1987; 6(2).

25. Fitzgerald F. The problem of obesity. Аnпи Rev Med 1981; 32: 221-31.

\title{
CONSUMERS FIRST: PARTICIPATING IN THE SYSTEM
}

\section{Elizabeth McDonald}

Croydon, New South Wales

As a retired social worker, and a person with a severe physical disability, I have had the opportunity to view the health system from both points of view. This article gives a personal reflection on the contribution that consumers might make to address the inequalities evident in health services.

\section{A PERSONAL ENCOUNTER}

It seems to me that, as in most organisations, health services are 'compartmentalised'. Each section, department, ward, or service, has its own brief; if the individual does not fit into that particular brief then they can have difficulty in accessing the assistance they need. My own quest to be weighed falls into this category of problems. I must say that this has not become an obsession, and that I may well have succeeded in being weighed if I had persevered.

To explain, I use an electric wheelchair and am not able to transfer without a lifter. Some years ago I was able to be weighed at a facility by a friend — of one of the health professionals I was seeing at the time-during her lunch hour. This solved the problem at the time. However, I was conscious that, had there been an accident of some sort, I was not a 'patient' of the facility and this could have caused difficulties for the person concerned. At the time I had to have some dietary advice and, as I had private health cover for extras, I began to attend a private clinic that also did not have the facility to weigh me. The dietician and I tried the hospital kitchen with the plan to weigh me in the wheelchair and then subtract the weight of the chair. Unfortunately, the new kitchen scales were not suitable.
My next attempt, a couple of years later, was when I had a short inpatient admission that I knew would involve a transfer from chair to bed. Armed with a request from my doctor I requested that, when I was being transferred, I might be weighed on a weighing chair. No luck again. There was no weighing chair on the ward and the staff were too busy to borrow one. My latest attempt has been to enquire of another community health professional if there was some way I could be weighed by someone in her community health service. Well no. I would have to see the dietician for that service.

I present this experience as an illustration of the difficulties faced by a person with a disability in accessing a simple service - to be weighed. Such a problem would be even greater if I did not speak English and/or had no knowledge of the health system. Although the service would be simple to provide, the complexity of the 'system' has prevented access.

\section{THE INTERFACE WITHTHE CONSUMER INTHE COMMUNITY}

This same topic of compartmentalised responsibilities is evident in the interface between health and other community services. This interface was described in a 1996 report for the Consumers First Project. ${ }^{1}$ The report examined the problems associated with the different areas of care, including health services (both hospital and community based), home and community care services, Department of Community Services, and nongovernmental service providers. Twenty-six case studies cover a wide range of situations, ages, ethnicity, and disability. They show how differing services, responsibilities, and lack of communication between and within services can affect the outcome for consumers. 
Examples of the problems encountered include lack of coordination of services, poor discharge planning, and lack of knowledge about services. In several cases, lack of knowledge on the part of general practitioners was a factor in the delay in accessing services, to both services in the community and services associated with the health system. Given that the general practitioner is the point of access in many cases, this can cause situations to become exacerbated before a remedy is found. In my own experience, I have been aware of services and have been able to track down what I needed. But I can understand the frustration of those without the knowledge of 'where to start' and those who give up the search for help.

\section{THE PLACE OF THE CONSUMER}

\section{Complaints}

The complaints procedure can play a part in improving services by drawing attention to individual problems; no doubt complaints might bring about some improvements in individual areas. However, one cannot know with certainty whether the situation has improved until the same situation occurs again. I had occasion to complain at the lack of a lifter in an emergency department when I had to be lifted manually by four people. I have been told that a note that I require this equipment has been put on my records at the hospital but what of others in a similar situation? I do not know whether, after my complaint, there is now a patient lifter available in that emergency department. Fortunately, I have not had the occasion to find out.

Apart from rectifying the situation that led to the original complaint, administrators might well look at the total situation regarding that complaint-in this case: Are there other areas where a lifter could-should be used? Are there any Occupational Health and Safety Issues? What of the dignity or preference of the patient? And so on.

\section{Advisory Committees}

A more proactive approach is to attempt to anticipate problems that may occur. As a person with a disability, I have participated in a number of advisory and planning committees such as Local Council Access Committees, the above mentioned Consumers First Project, Home and Community Care Planning Committees, and Disability Area Planning Committees. I see such committees, made up of representatives of consumers and other stakeholders, as playing an important part in improving services, particularly to special groups within the community.

Such advisory committees are particularly advantageous when planning facilities. A successful recent example of such a committee has been the Olympic Games Access Committee. Made up of representatives from all disability groups, this committee advised on all aspects of access to the Olympic site. There have been many comments, both at the time and since, about the ease of access to the facilities. The advice given in such planning situations can not only provide easier access to any facility but can also have potentially positive results in that it removes the need for costly changes afterwards and the possibility of legal action under the Disability Discrimination Act.
The Consumers First Project involved consumers, health professionals, and other stakeholders in discussions about the interface between health systems and community services. Though this project has ceased, much was learned by those participating, which no doubt had some influence on the ways in which the problems were approached.

\section{CONCLUSION}

Consumer and community participation has a value in various ways. On one level, participation can influence decision-making, especially the planning stages for new projects, whether in physical aspects such as disability access or access to the system itself. On another level the participation of the health professional, along with the consumers, hopefully will enable those within the system to see with new eyes, the inequalities, gaps, and difficulties in the ways in which services are delivered. Similarly, consumers can gain a fresh appreciation of the challenges of working within the health system.

While long-term committees can provide a reservoir of knowledge and expertise, it is important that there be a focus and task for such a group. Inequality in health may be the result of poverty, disability, ignorance, language, custom, and even low self-esteem on the part of the consumer. The health system itself is complex and can be difficult to negotiate. It has been likened to 'jumping through hoops'. Consumer groups and individuals can help to remove these hoops by working with members of the health professions to identify barriers and seek to remove them.

\section{REFERENCE}

1. For Your Eyes Only-Consumers First Project Case Study Report. Sydney: Ageing Agendas, 1996.

\section{COMMUNITY AND CONSUMER PARTICIPATION IN HEALTH: THE HEALTH PARTICIPATION COUNCIL}

The Government Action Plan for health emphasised the importance of consumer and community participation in decisions about the public health system, and made a number of recommendations to strengthen this.

The recommendations included the establishment of a Health Participation Council, a ministerial advisory council appointed for two years, to provide input into policy decisions made at a state level. In addition, a new unit of the NSW Department of Health was established in the Consumer and Community Development Branch. For more information on consumer and community participation in health visit the Web site at www.health.nsw.gov.au/policy.participate.

A future issue of the NSW Public Health Bulletin will highlight some of the consumer and community participation initiatives that are currently underway in New South Wales. 